\title{
Pengaruh Brand Image Terhadap Keputusan Berkunjung Wisatawan Nusantara Ke Sari Ater Hotel \& Resort, Subang
}

\author{
Anthonny Susanto*1, Prashad Akbar Laksana², Winda Gafrilia Prianka ${ }^{3}$ \\ Sekolah Tinggi Pariwisata Bandung, Indonesia ${ }^{1,2,3}$ \\ Email: anthonny.susanto@gmail.com
}

\begin{abstract}
Brand image (Brand Image) is a representation of the overall perception of the brand and is formed from information and past experience of the brand. The image of a brand is related to attitudes in the form of beliefs and preferences towards a brand. A good brand is a key to success for a company in achieving sales targets. The high level of competition, makes consumers have an attitude towards a brand (brand). Tourist destinations that have a positive image will further convince consumers to make a visit. Sariater Hotel \& Resort as one of the very popular tourist destinations in Subang Regency always strives to maintain and improve all important aspects that are important so that tourists will come to visit. The goal is carried out by giving the best service, Sariater Hotel \& Resort always makes a good brand image for tourists. In this study, the independent variable $(\mathrm{X})$ used is the brand image which consists of the strength of the brand association, the benefits of the brand association and the uniqueness of the brand association, while the independent variable $(\mathrm{Y})$ used is the decision to visit. This type of research is descriptive verification. The population in this study were all characteristics that visited Sariari Hotel \& Resort. The sampling technique used is Nonprobability sampling by incidental sampling so that the sample obtained is 100 tourists visiting Sariater Hotel \& Resort. Data analysis and hypothesis testing techniques used are multiple regression methods. The results showed that brand image had a significant effect on visiting decisions. The factor that most influences the visit decision is the strength of the brand association. This is supported because the information that enters the consumer's memory is very strong and the information survives as the brand image of the Sariater Hotel \& Resort to increase the number of tourist visits.
\end{abstract}

Keywords: Brand Image, Visit Decision, Sariater.

\begin{abstract}
Abstrak
Citra merek (Brand Image) merupakan representasi dari keseluruhan persepsi terhadap merek dan dibentuk dari informasi dan pengalaman masa lalu terhadap merek itu. Citra terhadap merek berhubungan dengan sikap yang berupa keyakinan dan preferensi terhadap suatu merek. Merek yang baik merupakan sebuah kunci kesuksesan untuk sebuah perusahaan dalam meraih target penjualan. Tingginya tingkat persaingan, membuat konsumen memiliki sebuah sikap terhadap sebuah merek (brand). Destinasi wisata yang memiliki citra yang positif, akan lebih meyakinkan konsumen untuk melakukan kunjungan. Sariater Hotel \& Resort sebagai salah satu destinasi wisata yang sangat popular di Kabupaten Subang selalu berupaya mempertahankan dan meningkatkan segala aspek penting yang penting agar wisatawan mau datang berkunjung. Tujuan tersebut dilakukan dengan cara meberikan pelayanan yang terbaik, Sariater Hotel \& Resort selalu membuat citra merek yang baik bagi wisatawan. Dalam penelitian ini, variabel bebas $(\mathrm{X})$ yang digunakan yaitu brand image yang terdiri dari kekuatan asosiasi merek, keuntungan asosiasi merek dan keunikan asosiasi merek, sedangkan variabel tidak terikat (Y) yang digunakan yaitu keputusan berkunjung. Jenis penelitian yang digunakan adalah deskriptif verifikatif. Populasi dalam penelitian ini adalah seluruh karakteristik yang berkunjung di Sariater Hotel \& Resort. Teknik sampling yang digunakan adalah Nonprobability sampling dengan cara Sampling Insidental sehingga sample yang didapatkan adalah 100 wisatawan yang berkunjung ke Sariater Hotel \& Resort. Teknik analisis data dan uji hipotesis yang digunakan adalah metode regresi berganda. Hasil Penelitian menunjukan bahwa brand image berpengaruh signifikan terhadap keputusan berkunjung. Faktor yang paling mempengaruhi keputusan berkunjung adalah kekuatan asosiasi merek hal ini didukung karena informasi yang masuk kedalam ingatan konsumen sangat kuat dan informasi itu bertahan sebagai brand image dari Sariater Hotel \&
\end{abstract}


Resort tersebut, aspek ini perlu menjadi perhatian agar Sariater Hotel \& Resort dapat mengoptimalkan brand image untuk meningkatkan jumlah kunjungan wisatawan.

Kata Kunci: Brand Image, Keputusan Berkunjung, Sariater.

\section{A. PENDAHULUAN}

Merek (brand) merupakan salah satu aset tidak berwujud dan bagi perusahaan merupakan aset yang paling penting karena merupakan dasar keuntungan kompetitif dan sumber pendapatan di masa yang akan datang. Suatu merek merupakan sebuah identitas terhadap suatu perusahaan. Merek mampu memikat setiap konsumen agar membeli produk atau jasa yang dimilikinya. Merek yang baik merupakan sebuah kunci kesuksesan untuk sebuah perusahaan dalam meraih target penjualan. Tingginya tingkat persaingan, menimbulkan banyaknya merek (brand) terhadap produk sejenis yang beredar di pasaran. Di situasi ini, konsumen memiliki sebuah sikap terhadap sebuah merek (brand) dimana konsumen cenderung mempelajari dan mengevaluasi sebuah merek yang disukai maupun tidak disukai. Oleh karena itu sangat diperlukan sebuah perusahaan menciptakan brand image (citra merek) yang baik di mata konsumen. Merek adalah produk atau jasa lainnya yang dirancang untuk memuaskan kebutuhan. Kebutuhan setiap konsumen pun berbeda-beda sehingga merek dapat memuaskan kebutuhan setiap konsumen dengan lebih bersifat simbolis, emosional, atau tidak nyata dengan apa yang direpresentasikan oleh merek. Menurut Methaq Ahmed Sallam dalam jurnal The Impact of Brand Image and Corporate Branding on Consumer's Choice: The Role of Brand Equity brand image adalah "Consumers employ a product's brand image in deriving overall perceptions of the specified product, a product with higher brand image may be inferred by consumers as product of superior quality and value". Kemampuan konsumen untuk mengidentifikasi suatu merek pada kondisi yang berbeda, dapat dilakukan dengan pengenalan merek dan pengingatan kembali terhadap suatu merek tertentu. Kesadaran merek diciptakan dan ditingkatkan dengan cara meningkatkan keakraban merek melalui paparan berulang sehingga konsumen merasa mengenal merek tersebut. Dalam jurnal Pengaruh Brand Awareness, Brand Image, dan Media Communication Terhadap Keputusan Pembelian oleh Wulan Suciningtyas "Citra dipengaruhi oleh banyak faktor yang di luar kontrol perusahaan. Citra yang efektif akan berpengaruh terhadap tiga hal yaitu: pertama, memantapkan karakter produk dan usulan nilai. Kedua, menyampaikan karakter itu dengan cara yang berbeda sehingga tidak dikacaukan dengan karakter pesaing. Ketiga, memberikan kekuatan emosional yang lebih dari sekadar citra mental. Supaya bisa berfungsi, citra harus disampaikan melalui setiap sarana komunikasi yang tersedia dan kontak merek". Sehingga pada penelitian ini kami menyimpulkan bahwa brand image adalah sebuah merek yang terkenal dan terpercaya merupakan aset yang tidak ternilai. Keahlian yang paling unik dari pemasaran yang profesional adalah kemampuannya untuk menciptakan, memelihara, melindungi, dan meningkatkan merek. Citra merek (Brand Image) merupakan representasi dari keseluruhan persepsi terhadap merek dan dibentuk dari informasi dan pengalaman masa lalu terhadap merek itu. Citra terhadap merek berhubungan dengan sikap yang berupa keyakinan dan preferensi terhadap suatu merek. Konsumen yang memiliki citra yang positif terhadap suatu merek, akan lebih memungkinkan untuk melakukan pembelian.

Subang merupakan salah satu kabupaten wilayah di Jawab Barat yang memiliki primadona pariwsata domestik maupun mancanegara. Secara geografis kabupaten subang terletak di wilayah pantura, sebelah utara berbatasan dengan laut jawa, selatan berbatasan dengan Bandung, barat berbatasan dengan Karawan dan Purwakarta dan di timur berbatasan dengan Kabupaten Indramayu dan Sumedang. 
Pada saat ini, Subang lebih dikenal sebagai daerah wisata karena banyaknya destinasi wisata, seperti wisata alam, budaya maupun kuliner. Semakin mudahnya akses untuk berkunjung ke Kabupaten Subang, Dengan dibukakannya akses Tol Cipali (Cikopo-Palimanan) menjadikan tren wisatawan yang berkunjung ke wilayah Subang semakin meningkat.

Permasalahan yang muncul, dengan banyaknya akses menuju Kabupaten Subang salah satunya adalah masalah kemacetan. Semakin ke sini, aksesibilitas ke Subang semakin kurang nyaman pada faktor transportasi. Kemacetan antara jalur penghubung Kabupaten Subang dan lembang masih jadi permasalahan klasik. Parahnya, di jalan - jalan alternatif pun kini terjadi kemacetan parah. Tak heran bila waktu tempuh pun semakin lama.

Masalah lainnya adalah lahan parkir, tata kelola dan koordinasi masih perlu banyak dibenahi. Bila saat musim liburan panjang, tidak sedikit wisatawan yang merasa sangat tidak nyaman dengan naiknya tarif parkir dan banyaknya pungutan liar dari oknum - oknum yang tidak bertanggung jawab. Situasi ini dapat merusak citra pariwisata dan fenomena

tersebut terjadi tidak hanya di Bandung saja melainkan di Kota lain pun fenomenanya hampir sama. Dalam hal ini perlu adanya edukasi kepariwisataan, khususnya kepada para penduduk yang ada disekitar destinasi wisata.

Banyaknya destinasi wisata di Kabupaten Subang membuat kota ini dikunjungi oleh para wisatawan nusantara. Berdasarkan data yang dihimpun oleh Badan Pusat Statistik tahun 2016, sebanyak 3.477.300 tercatat jumlah wisatawan yang datang ke Kabupaten Subang. Dengan data tersebut hampir setengah jumlah wisatawan mengunjungi ke destinasi wisatawan Sari Ater Hotel \& Resort. Tabel 1 adalah dan tabel 2 data jumlah wisatawan yang datang ke Sari Ater Hotel \& Resort.

Tabel 1 Jumlah Pengunjung Wisatawan Nusantara Di Sari Ater Hotel \& Resort

\begin{tabular}{lc}
\hline Tahun & $\begin{array}{c}\text { Jumlah Kunjungan Wisawatan } \\
\text { Nusantara }\end{array}$ \\
\hline 2012 & 1.842 .599 \\
\hline 2013 & 1.665 .017 \\
\hline 2014 & 1.674 .249 \\
\hline 2015 & 1.401 .181 \\
\hline 2016 & 1.437 .356 \\
\hline Sumber :
\end{tabular}

Berdasarkan data kunjungan banyak wisatawan nusantara yang datang ke Sari Ater Hotel \& Resort maka perlu dilakukannya penelitian tentang brand image.

\section{Tabel 2 Jumlah Pengunjung Wisatawan Nusantara Di Sari Ater Hotel \& Resort}

\begin{tabular}{|c|c|}
\hline Tahun & Jumlah Kunjungan Wisawatan Mancanegara \\
\hline 2012 & 12,493 \\
\hline 2013 & 16,869 \\
\hline 2014 & 28,437 \\
\hline 2015 & 24,679 \\
\hline 2016 & 41,800 \\
\hline
\end{tabular}

Sumber : Data Kunjungan Wisman Sari Ater

Brand image adalah penilaian konsumen terhadap merek tersebut dalam sebuah pasar. Penciptaan tersebut dapat tercipta berdasarkan pengalaman pribadi maupun mendengar reputasinya dari orang lain atau media (Aaker and Biel, 1993). Citra merek adalah sekumpulan asosiasi mengenai suatu merek yang 
tersimpan dalam benak atau ingatan konsumen (Schiffman and Kanuk, 2007). Untuk memudahkan penelitian yang kami lakukan, maka kami memilih satu tempat wisata yang dijadikan sebagai tempat untuk diteliti. Oleh karena itu, kami memilih tempat permandiang air panas Ciater atau sekarang terkenal dengan nama Sari Ater Hotel dan Resort.

Wisata ke pemandian air panas di Sari Ater Hotel dan Resort adalah suatu destinasi wisata yang sangat popular di Kabupaten Subang. Setiap bulannya, tempat pemandian air panas Sari Ater ini dapat mendatangkan pengunjung kurang lebih sebanyak 70.000 orang. Para pengunjung yang datang tidak hanya para wisatawan nusantara sekitar Subang dan sekitarnya saja, namun juga banyak yang datang dari berbagai kota besar di Indonesia.

Penelitian ini peneliti lakukan dengan tujuan untuk mengetahui gambaran brand image yang ada di Sari Ater, mengetahui keputusan wisatawan untuk mengunjungi Sari Ater, dan mengetahui pengaruh brand image terhadap keputusan mengunjungi Sari Ater. Manfaat penelitian ini adalah dapat memperluas kajian ilmu pemasaran khususnya pada bidang destinasi pariwisata melalui pengaruh brand Image terhadap keputusan berkunjung.

Peneliti juga telah melakukan pencarian terhadap 5 (lima) penelitian terdahulu tentang brand image. Dari kelima penelitian terdahulu tersebut belum ada yang meneliti tentang pengaruh brand image terhadap keputusan berkunjung. Selain itu dari kelima penelitian yang kami dapatkan, kelimanya belum meneliti pada objek penelitian di destinasi wisata. Sehingga peneliti memutuskan bahwa penelitian ini berjudul "Pengaruh Brand Image Terhadap Keputusan Berkunjung Wisatawan Nusantara di Sari Ater, Kabupaten Subang"

\section{B. METODE PENELITIAN}

\section{Objek Penelitian}

Sari Ater Hotel dan Resort merupakan sebuah kawasan wisata yang berlamat di Jalan Raya Ciater, Kecamatan Ciater, Kabupaten Subang. Lokasinya berbatasan langsung dengan Bandung Utara atau Kabupaten Bandung Barat. Sari Ater Hotel \& Resort Subang selama ini dikenal sebagai salah satu destinasi wisata favorit dan sangat populer bagi wisatawan yang di dominasi oleh wisatawan nusantara. Kawasan destinasi wisata ini memang banyak sekali menawarkan daya tarik wisata khas bumi parahyangan, serta ditunjang banyak sekali fasilitas wisata yang membuatnya menjadi destinasi wisata yang lengkap dan sangat nyaman dijadikan tempat liburan atau rekreasi.

\section{Metode Penelitian}

Berdasarkan variabel-variabel yang diteliti maka jenis-jenis penelitian ini adalah penelitian deskriptif verifikatif. Menurut Ir. Sofyan Siregar (2013, hml 7) penelitian deskriptif adalah penelitian yang dilakukan untuk mengetahui nilai veriabel mandiri, baik satu variabel atau lebih (Independent) tanpa membuat perbandingan, atau penghubung dengan variabel lain" Tujuan dari metode deskriptif itu sendiri menurut Moh.Nazir (2011, hml. 54) adalah "untuk membuat deskripsi, gambaran atau lukisan secara sistematis, faktual, dan akurat mengenai fakta-fakta, sifat-sifat serta hubungan antar fenomena yang diselidiki". Melalui jenis penelitian deskriptif, maka dapat diperoleh gambaran mengenai implementasi 1) Brand Image di Sari Ater Hotel dan Resort, 2) Keputusan berkunjung di Sari Ater Hotel \& Resort.

Verifikatif pada dasarnya ingin menguji kebenaran suatu hipotesis yang dilaksanakan melalui pengumpulan data dilapangan dimana pengujian hipotesis tersebut menggambarkan perhitungan statistik, maka diperoleh gambaran mengenai implementasi pengaruh brand image terhadap keputusan berkunjung di Sari Ater Hotel \& Resort. Berdasarkan uraian mengenai jenis penelitian di atas, maka jenis 
penelitian yang digunakan yaitu penelitian deskriptif dan penelitian verifikatif, maka metode yang digunakan yaitu desktiptif verifikatif.

\section{Populasi}

Populasi menurut Ir. Sofyan Siregar (2011, hml. 30) adalah populasi berasal dari kata bahasa Inggris yaitu population yang berarti jumlah penduduk. Dalam penelitian, kata populasi amat populer dipakai untuk menyebutkan serumpun / sekelompok objek yang menjadi sasaran penelitian. Populasi penelitian merupakan keseluruhan dari objek penelitian yang dapat berupa manusia, hewan tumbuhtumbuhan, udara, gejala, nilai, peristiwa, sikap hidup dan sebagainya. Berdasarkan pengertian tersebut, maka populasi dalam penelitian ini adalah seluruh karakteristik yang mempengaruhi keputusan berkunjung di Sari Ater Hotel \& Resort. Jumlah populasi berdasarkan hasil kumulatif dari beberapa segmen pasar. Namun dalam penelitian ini, penulis hanya akan mengambil jumlah populasi yang termasuk kedalam kategori individual saja.

\section{Sample}

Menurut Ir. Syofian Siregar (2011, hml. 30) "sampel adalah suatu prosedur pengambilan data di mana hanya sebagian populasi saja yang diambil dan dipergunakan untuk menentukan sifat serta ciri yang di kehendaki dari suatu populasi.

Berdasarkan pengertian sampel yang dikemukakan diatas, maka sampel yang digunakan dalam penelitian ini adalah sebagian dari populasi penelitian, yaitu sebagian dari tamu yang berkunjung di Sari Ater Hotel \& Resort.

Adapun rumus yang digunakan untuk mengukur sampel, digunakan rumus Solvin (Husen Umar 2010,hml.146) yakni ukuran sampel yang merupakan perbandingan dari ukuran populasi dengan presentasi kelonggaran ketidak telitian, karena dalam pengambilan sampel dapat ditolelir atau diinginkan. Dalam pengambilan sampel digunakan taraf kesalahan sebesar 5\%. Adapun rumus yang digunakan sebagai berikut:

$$
n=\frac{N}{1+N e^{2}}
$$

\section{Dimana :}

$\mathrm{n}=$ ukuran sampel

$\mathrm{N}=$ ukuran populasi

$\mathrm{E}=$ kelonggaran ketidakterkaitan karena kesalahan sampel dapat di tolerin $(\mathrm{e}=0,1)$

Berdasarkan perhitungan pada rumus Solvin, maka ukuran sampel pada penelitian ini adalah sebagai berikut :

$$
\begin{aligned}
n= & \frac{8.144 .599}{1+8.144 .599 * 0,1^{2}} \\
= & \frac{8.144 .599}{1+8.144 .599 * 0,01} \\
& =\frac{8.144 .599}{1+81,445} \\
& =\frac{8.144 .599}{82,445} \\
& =98,78
\end{aligned}
$$

Sampel penelitian ini berjumlah 98,788 atau 100 responden 


\section{Teknik Sampling}

Menurut Sugiyono (2010, hml. 62) teknik sampling adalah "merupakan teknik pengambilan sampel". Untuk menentukan sampel yang akan digunakan dalam penelitian terdapat berbagai teknik sampling yang digunakan.

Menentukan ukuran sampel merupakan bagian dari teknik sampling, dimana jumlah anggota sampel sering dinyatakan dengan ukuran sampel. Jumlah sampel yang $100 \%$ mewakili populasi adalah sama dengan populasi. Semakin besar jumlah sampel mendekati populasi, maka peluang kesalahan generalisasi semakin kecil dan sebaliknya semakin kecil jumlah sampel menjauhi populasi, maka akan semakin besar kesalahn generalisasi (diberlakukan).

Dalam prakteknya, sangat jarang penelitian yang menerapkan sensus dalam upaya pengumpulan datanya karena keterbatasan dalam operasionalnya. Sehingga penelitian seringkali menggunakan teknik sampling.

Dalam penelitian ini, teknik sampling yang digunakan adalah Nonprobability sampling dengan cara Sampling Insidental, yaitu teknik penentuan sampel berdasarkan kebetulan, siapa saja yang secara kebetulan/incidental bertemu dengan peneliti dapat digunakan sebagai sampel, bila dipandang orang yang kebetulan ditemui itu cocok sebagai sumber data Sugiyono (2013, hlm 96). Sampel diambil dari keseluruhan poupulasi wisatawan Sari Ater Hotel \& Resort berjumlah 100 orang.. Pemilihan sampel secara acak sederhana adalah proses pemilihan sampel dalam cara tertentu yang didalamnya semua elemen dalam populasi didefinisikan mempunyai kesempatan yang sama. Bebas dan seimbang dipilih menjadi sampel. Ini berarti sampel acak sederhana adalah sejumlah element sampel yang secara random dipilih dari elemen populasi terdaftar.

\section{Teknik Pengumpulan Data}

Teknik pengumpulan data merupakan suatu proses pengadaan untuk keperluan penelitian dimana data yang terkumpul adalah untuk menguji hipotesis yang telah dirumuskan. Adapun teknik pengumpulan data yang penulis gunakan adalah :

a) Studi Kepustakaan

b) Mengadakan penelitian dengan membaca literatur maupun sumber-sumber lainnya yang kaitannya dengan masalah yang diteliti. Studi kepustakaan disini juga merupakan usaha pengumpulan informasi yang berhubungan dengan teori-teori yang ada kaitannya dengan masalah variabel yang diteliti.

c) Studi Lapangan

d) Penelitian yang dilakukan pengamatan secara langsung terhadap objek penelitian yang diteliti dengan instrumen-instrumen sebagai berikut:

1. Interview (wawancara)

2. Menurut Ir.Sofyan Siregar (2011, hml. 18) adalah proses memperoleh keterangan/data untuk tujuan penelitian dengan cara tanya jawab, sambil bertatap muka antara pewawancara dengan responden dengan menggunakan alat yang dinamakan panduan wawancara.

3. Kuesioner (angket)

4. Menurut Ir. Sofyan Siregar (2011, hml. 21) adalah teknik pengumpulan informasi yang memungkinkan analis mempelajari sikap-sikap, keyakinan, perilaku dan karakteristik beberapa orang utama di dalam organisasi yang bisa terpengaruh oleh sistem yang diajukan atau oleh sistem yang sudah ada.

5. Observasi 
Menurut Ir. Sofyan Siregar (2011, hml. 19) adalah kegiatan pengumpulan data dengan melakukan penelitian langsung terhadap kondisi lingkungan objek penelitian yang mendukung kegiatan penelitian, sehingga dapat digambarkan secara jelas tentang kondisi objek penelitian tersebut.

\section{HASIL DAN ANALISIS}

\section{Hasil Uji Instrumen}

Berdasarkan output Qtotal pada lampiran, hasil pada tabel 3 menunjukan bahwa pertanyaan 1 sampai 13 adalah valid karena nilai Q hitung lebih besar dari 0,05.

Tabel 3 Hasil Uji Validitas

\begin{tabular}{|c|c|}
\hline No & r hitung \\
\hline Q1 & $.702^{* *}$ \\
\hline Q2 & $.529^{* *}$ \\
\hline Q3 & $.539^{* *}$ \\
\hline Q4 & $.490^{* *}$ \\
\hline Q5 & $.578^{* *}$ \\
\hline Q6 & $.497^{* *}$ \\
\hline Q7 & $.503^{* *}$ \\
\hline Q8 & $.524^{* *}$ \\
\hline Q9 & $.617^{* *}$ \\
\hline Q10 & $.498^{* *}$ \\
\hline Q11 & $.523^{* *}$ \\
\hline Q12 & $.508^{* *}$ \\
\hline Q13 & $.662^{* *}$ \\
\hline Sumber : Pengolahan Data, 2018
\end{tabular}

Tabel 4 Reliability Case Processing Summary

\begin{tabular}{|ll|l|l|}
\hline & & $\mathrm{N}$ & $\%$ \\
\hline \multirow{3}{*}{ Cases } & Valid & 100 & 100.0 \\
& Excluded & \\
& Total & 0 & .0 \\
& Total & 100 & 100.0 \\
\hline
\end{tabular}

a. Listwise deletion based on all variables in the procedure.

Reliability Statistics

Cronbach's Alpha $\mathrm{N}$ of Items

\begin{tabular}{l|l}
.739 & 14 \\
\hline
\end{tabular}

Sumber : Pengolahan Data, 2018 
Berdasarkan hasil pengujian reliabilitas pada tabel 4, diketahui angka cronbach alpha sebesar 0,739. Jadi angka tersebut lebih besar dari nilai minimal cronbach alpha 0,6. Oleh karena itu, dapat disimpulkan bahwa instrumen penelitian yang digunakan untuk mengukur variable brand image dapat dikatakan reliable atau handal.

\section{Karakteristik Responden}

Penelitian ini dilakukan pada bulan Mei 2018 dengan melibatkan 100 orang wisatawan yang berkunjung ke Sari Ater sebagai responden. Berdasarkan pengolahan data peneliti 2018, setiap responden memiliki jenis kelamin yang terdiri dari $51 \%$ pria dan $49 \%$ wanita, rentan usia yang paling banyak berkunjung adalah 21-30, dan asal tinggal wisatawan yang berkunjung ; Jakarta 32\%, Bekasi 7\%, Tanggerang 4\%, Depok 11\%, dan Daerah lainnya sebanyak 46\%.

\section{Analisis Deskriptif}

Tabel 5 Penilaian Wisatawan Terhadap Brand Image

\begin{tabular}{lll}
\hline \multicolumn{3}{c}{ Variabel Brand Image } \\
\hline Dimensi & Rata-Rata & Kategori \\
\hline Keunggulan Asosiasi Merk & 3.89 & Baik \\
\hline Kekuatan Asosiasi Merk & 3.83 & Baik \\
\hline Keunikan Asosiasi Merk & 4.00 & Baik \\
\hline Rata-rata & 3.91 & Baik \\
\hline
\end{tabular}

Sumber : Pengolahan Data, 2018

Berdasarkan tabel 5 diketahui bahwa dimensi keunikan asosiasi merk memiliki skor tertinggi yang berarti bahwa Sari Ater memiliki keunikan tersendiri di benak wisatawan. Secara keseluruhan Variabel Brand image memiliki penilaian yang baik jika dilihat dari presepsi wisatawan. Hal ini didukung oleh teori dari sugiyono (2002 : 81) dengan rentang 3,4 - 4,1 dikategorikan baik.

Tabel 6 Penilaian Wisatawan Terhadap Keputusan Berkunjung

\begin{tabular}{|c|c|c|}
\hline \multicolumn{3}{|c|}{ Variabel Keputusan Berkunjung } \\
\hline Dimensi & Rata-Rata & Kategori \\
\hline Pemilihan Produk & 3.82 & Baik \\
\hline Pilihan Merk & 3.74 & Baik \\
\hline Pilihan Penyalur & 3.74 & Baik \\
\hline Jumlah Pembelian & 3.83 & Baik \\
\hline Waktu Pembelian & 3.74 & Baik \\
\hline Rata-rata & 3.77 & Baik \\
\hline
\end{tabular}

Sumber : Pengolahan data, 2018

Berdasarkan tabel 6 diketahui bahwa dimensi jumlah pembelian memiliki skor tertinggi yang berarti bahwa wisatawan yang berkunjung ke Sari Ater bersedia membeli lebih dari 1 jenis produk/jasa dan bersedia membeli lebih dari 1 kali pembelian dalam kurun waktu satu tahun. Secara keseluruhan Variabel keputusan berkunjung memiliki penilaian yang baik jika dilihat dari presepsi wisatawan. Hal ini didukung oleh teori dari sugiyono (2002 : 81) dengan rentang 3,4 - 4,1 dikategorikan baik. 


\section{Pengujian Hipotesis}

Dari hasil regresi yang kami lakukan dengan menggunakan software SPSS, kami mendapatkan persamaan regresi yaitu $: Y=35,412+0,638 \mathrm{X} 1+0,28 \mathrm{X} 2+0,162 \mathrm{X} 3+$ e. Dari persamaan tersebut peneliti dapat mengetahui seberapa besar pengaruh dari setiap variabel bebas yang diteliti terhadap $Y$ (variabel dependen).

$$
\begin{gathered}
Y=a+b 1 X 1+b 2 X 2+b 3 X 3+e \\
Y=35.412+0.638 X 1+0.28 X 2+0.162 X 3+e
\end{gathered}
$$

\begin{tabular}{|c|c|c|c|c|c|}
\hline \multirow[t]{2}{*}{ Model } & \multicolumn{2}{|c|}{$\begin{array}{c}\text { Unstandardized } \\
\text { Coefficients } \\
\end{array}$} & \multirow{2}{*}{$\begin{array}{l}\begin{array}{l}\text { Standardized } \\
\text { Coefficients }\end{array} \\
\text { Beta } \\
\end{array}$} & \multirow[t]{2}{*}{$\mathrm{t}$} & \multirow[t]{2}{*}{ Sig. } \\
\hline & $\mathrm{B}$ & Std. Error & & & \\
\hline (Constant) & 35.412 & 4.858 & & 7.290 & .000 \\
\hline $\mathrm{X} 1$ & .638 & .319 & .244 & 1.999 & .048 \\
\hline $\mathrm{X} 2$ & .280 & .290 & .107 & .966 & .337 \\
\hline X3 & .162 & .261 & .075 & .622 & .535 \\
\hline
\end{tabular}

Tabel 7 Coefficients

Sumber : Pengolahan data, 2018

Jika kita lihat dari tabel 7 dapat diketahui bahwa besar signifikansi dari variabel kekuatan asosiasi merek (X1) yaitu sebesar 0,048 maka variabel X1 ini berpengaruh terhadap keputusan mengunjungi dari setiap pengunjung yang datang. Hal ini dikarenakan besarnya signifikansi yang diperoleh di tabel lebih kecil dari 0,05. Jika dilihat dari persamaan Y, dapat dilihat jika X2 dan X3 dianggap 0 maka X1 dapat mempengaruhi $Y$ sebesar 36,05. Dari hasil tersebut, kekuatan asosiasi merek memberikan pengaruh sebesar 36,05 kepada keputusan berkunjung.

Dari pembahasan ketiga dimensi yang telah kami lakukan dengan melihat tabel spss, maka dapat dilihat bahwa dimensi yang paling mempengaruhi keputusan berkunjung adalah kekuatan asosiasi merek (X1). Hal ini dikarenakan besarnya signifikansi yang diperoleh oleh kekuatan asosiasi merek lebih besar dari 0,05. Hal tersebut menyebabkan kekuatan asosiasi merek sangat berpengaruh dibandingkan dengan keunikan asosiasi merek dan keunggulan asosiasi merek. Selain itu, besarnya pengaruh yang diberikan oleh kekuatan asosiasi merek kepada keputusan berkunjung lebih besar dibandingkan dengan keuntungan asosiasi merek dan keunggulan asosiasi merek.

\section{SIMPULAN}

Berdasarkan hasil penelitian yang telah dilakukan terhadap brand image dan keputusan berkunjung di Sari Ater Hotel \& Resort maka dapat ditarik kesimpulan bahwa terdapat pengaruh brand image terhadap keputusan berkunjung di Sari Ater Hotel \& Resort. Namun dalam penelitian ini kami menggunakan 3 dimensi yaitu kekuatan asosiasi merek, keunggulan asosiasi merek dan keunikan asosiasi merek.

Dari ke 3 dimensi tersebut yang paling berpengaruh terhadap keputusan berkunjung adalah kekuatan asosiasi merek hal ini didukung karena informasi yang masuk kedalam ingatan konsumen sangat kuat dan informasi itu bertahan sebagai brand image dari Sari Ater Hotel \& Resort tersebut.

Hasil temuan menunjukan bahwa secara keseluruhan pengaruh brand image terhadap keputusan berkunjung di Sari Ater Hotel \& Resort memiliki hubungan yang cukup kuat dengan perolehan pada dimensi kekuatan asosiasi merek mencapai 63,8\%. Pada penelitian ini dapat disimpulkan bahwa brand image berpengaruh terhadap keputusan berkunjung. 


\section{DAFTAR REFERENSI}

Aaker, David A. And Biel, Alexander L., 1993, Brand Equity \& Advertising: Advertising's Role In Building Strong Brands. New Jersey: Lawrence Erlbaum Associates, Inc.

Ahmed, M, Sallam. (2016). The Impact of Brand Image and Corporate Branding on Consumer's Choice: The Role of Brand Equity. College of Administrative Scince, Najran University, Saudi Arabia.

Christiawan, F. Bramantya. Sutanto, R, P. (2014). Perancangan Destination Branding Kawasan Wisata Kuliner Lentog Tanjung Kabupaten Kudus. Jurnal DKV Adiwarna, Universitas Kristen Patra, 1 (4), hlm. 1 - 12

Kotler, P. \& Keller, K. (2012). Marketing Management (14th ed). Global Edition Pearson Prentice Hall.

Kotler, Philip dan Gary Armstrong, 2009, Prinsip-Prinsip Pemasaran, Edisi 12, jilid 2, Jakarta: Erlangga

Leliga, F, J. (2013). Analisis Pengaruh Brand Image Terhadap Customer Loyalty Dengan Satisfaction Sebagai Mediator Pada The Dreamland Luxury Villas And Spa, Bali. Jurnal Hospitality dan Manajemen Jasa, Universitas Kristen Patra, 1 (1), hal 1 -14.

Maulana, R, Setiawan. 2016. Analisis Pengaruh Service Quality dan Perceived Usefulness Terhadap Brand Image Serta Dampaknya Pada Brand Trust (Studi Kasus GO-JEK di DKI Jakarta). Fakultas Ekonomi dan Bisnis, UIN Syarif Hidayatullah Jakarta.

Nazir Mohammad, Ph.D (2011). Metode Penelitian. Jakarta : Ghalia Indonesia

Pitana, I Gde dan Putu G. Gayatri. 2005. Sosiologi Pariwisata. Yogyakarta : Andi.

Pramono, R, A. (2013). Pengaruh Brand Awarness, Perceived Quality Dan Brand Image Terhadap Brand Satisfaction Dan Brand Loyalty Pada Jasa Biro Perjalanan Antar Kota Di Kota Malang. Jurnal Aplikasi Manajemen, Universitas Brawijaya, 11 (3), hal 1 - 11.

Rai Utama, I Gusti Bagus dan Ni Made Eka Mahadewi, 2012, Metodologi Penelitian Pariwisata \& Perhotelan, CV Andi Offset, Yogyakarta.

Rangkuti, Freddy. 2009. The power of Brands. Jakarta: PT. GRamedia Pustaka Utama.

Schiffman dan Kanuk. 2007. Perilaku Konsumen. Edisi Kedua. Jakarta: PT. Indeks Gramedia

Setiawan, R, M. (2016). Analisis Pengaruh Service Quality dan Perceived Usefulness Terhadap Brang Image Serta Dampaknya Pada Brand Trust (Studi Kasus GO-JEK di DKI Jakarta). (Skripsi). Fakultas Ekonomi dan Bisnis, UIN Syarif Hidayatullah, Jakarta.

Siregar, Sofyan, Ir. M. M (2013). "Metode Penelitian Kuantitatif”. Jakarta: Kencana.

Suciningtyas, W. (2012). Pengaruh Brand Awareness, Brand Image, Dan Media Communication Terhadap Keputusan Pembelian. Managemen Analysis Jurnal.

Sugiyono. (2002). Teknik Analisis Regresi dan Korelasi bagi Para Peneliti. Bandung: Tarsito. . (2010). Metode Penelitian Administrasi. Cetakan Ke-19. Penerbit Alfabeta. Bandung.

(2013). Metode Penelitian Kuantitatif Kualitatif dan R\&D. Bandung: Alfabeta

Suwarduki, P, R. Yulianto, E. Mawardi, M, K. (2016). Pengaruh Electronic Word Of Mouth Terhadap Citra Destinasi Serta Dampaknya Pada Mindat Dan Keputusan Berkunjung (Survei Pada Followers Aktif Akun Instagram Indtravel Yang Telah Mengunjungi Destinasi Wisata Di Indonesia). Jurnal Administrasi Bisnis, Universitas Brawijaya, 37 (2), hal 1 - 10.

Tjokroaminoto, J dan Yohanes, S, Kunto. (2014). Analisa Pengaruh Brand Image Dan Company Image Terhadap Loyalitas Retailer Studi Kasus Pt Asia Paramita Indah. Manjemen Pemasaran, Universitas Kristen Petra. Surabaya.

Yanu, A, A, Fianto, Djumilah Hadiwidjojo, Siti Aisjah, \& Solimun. (2014). The Influence of Brand Image on Purchase Behavior Through Brand Trust. Fakultas Ekonomi dan Bisnis, Universitas Brawijaya. Malang.

Yi Zhang. (2014). The Impact of Brand Image on Consumer Behavior: A Literature Review. Department Marketing, mangement School, Jinan University, Guanzhou. China. 